\title{
Incidence of Pressure Ulcers in The Patients on Mechanical Ventilation: A Prospective Study
}

\author{
Mekanik Ventilatördeki Hastalarda Basınç Yarası İnsidansı: \\ Prospektif Bir Çalışma
}

\author{
Elif KARAHAN', @ Sevim ÇELIK', ๑ Özge UÇAR ${ }^{3}$ \\ 'Department of Nursing, Faculty of Health Sciences, Zonguldak Bulent Ecevit University, Turkey \\ ${ }^{2}$ Department of Nursing, Faculty of Health Sciences, Bartın University, Turkey \\ ${ }^{3}$ Institute of Health Sciences, Zonguldak Bulent Ecevit University, Turkey
}

\begin{abstract}
Aim: The aim of this study was to determine the incidence of pressure ulcers among the patients on mechanical ventilation.

Material and Method: The type of the study was cross-sectional and prospective. It was carried out in 5 intensive care units of a state hospital located in Western Black Sea region of Turkey. The sample of the study included 260 patients who were initiated mechanical ventilatory support. Pressure ulcer risk in patients was assessed by Braden Risk Assessment Scale at 10th hour, 1st week and 2nd week timepoints following the initiation of mechanical ventilatory support.
\end{abstract}

Results: Mean age of the patients was $54 \pm 10$ years old; $52.7 \%$ were males; and $55.4 \%$ had a Body Mass Index within normal range. It was determined that $46.5 \%$ of the patients were hospitalized due to the diagnosis of a cerebrovascular event; the state of consciousness was confused in 52.3\% and mean Braden Risk Assessment Scale was $11.0 \pm 2.64$. Pressure ulcer risk was found to be significatly higher among the patients who were females $(t=5.95, p=0.01)$, whose state of consciousness was stupor $(\mathrm{F}=97.56, \mathrm{p}=0.00)$ and whose motor response was localized to pain $(F=9.54, p=0.00)$. It was observed that the incidence of pressure ulcers was $10.8 \%$ at 10th hour, $58.5 \%$ at first week and $71.15 \%$ at second week from the start of mechanical ventilation treatment. At the end of second week, stage I pressure ulcer was developed on the sacrum in $30 \%$ and on coccyx area in $22.7 \%$ of the patients.

Conclusion: It was found that the incidence of pressure ulcer development risk was significantly high among the patients who underwent mechanical ventilation treatment. Considering the effect of mechanical ventilator and other factors, primary protective measures were suggested to be very important in the prevention of pressure ulcers.

Keywords: Mechanical ventilation, pressure ulcer, intensive care

\section{Öz}

Amaç: Bu çalışmanın amacı mekanik ventilatördeki hastalarda basınç yarası insidansını belirlemektir.

Gereç ve Yöntem: Araştırmanın tipi kesitsel tipte prospektiftir. Bat Karadeniz Bölgesinde yer alan bir Devlet Hastanesinin 5 yoğun bakım ünitesinde yürütülmüştür. Araştırmanın örneklemini mekanik ventilasyon desteği başlatılan 260 hasta oluşturmuştur. Braden Risk Değerlendirme Ölçek puanı ile hastalardaki basınç yarası oluşma riski mekanik ventilasyon desteği başladıktan sonra 10. saat, 1. hafta ve 2 . hafta zaman dilimlerinde değerlendirilmiştir. İstatistiksel analizlerde sayı, yüzde, ortalama, t testi, Anova ve Pearson Korelasyon analizi kullanılmıştır.

Bulgular: Hastaların yaş ortalaması 54 \pm 10 yaş; \%52,7'si erkek \%55,4'ünün Beden Kütle Indeksleri normal aralıktadır. Hastaların \%46,5'inde serebrovasküler olay tanısı ile yatış yapıldığı; \%52,3'ünün bilinç durumunun konfüze olduğu ve Braden Risk Değerlendirme Ölçek puanının 11,0 2,64 şeklinde yüksek risk grubunda olduğu belirlenmiştir. Kadın cinsiyette $(t=5,95, p=0,01)$, bilinç durumu stupor olan hastalarda ( $F=97,56, p=0,00)$ ve motor yanıtı ağrıya lokalize olan hastalarda $(F=9,54, p=0,00)$ basınç yarası riski anlamlı olarak daha yüksektir. Mekanik ventilasyon tedavisi başlatıldıktan sonraki 10. saatte basınç yarası insidansının \%10,8; birinci haftada \%58,5; ikinci haftada $\% 71,15$ olduğu görülmüştür. İkinci haftanın sonunda hastaların \%30'unda sakrum, \%22,7'sinde koksik bölgesinde Evre 1 basınç yarası gelişmiştir.

Sonuç: Mekanik ventilasyon tedavisi alan hastalarda ventilatörle ilişkili olarak basınç yarası gelişme insidansının oldukça yüksek olduğu sonucu ortaya çıkmıştır. Mekanik ventilatör ve diğer faktörlerin de etkisi göz önünde tutularak basınç yarasını önleme konusunda primer koruma önlemlerinin alınması oldukça önemlidir.

Anahtar Kelimeler: Mekanik ventilasyon, basınç yarası, yoğun bakım

Corresponding (illetişim): Elif KARAHAN, PhD, RN, Assistant Professor, Department of Nursing, Faculty of Health Sciences, Zonguldak Bulent Ecevit University, Turkey

E-mail (E-posta): elifim67@yahoo.com

Received (Geliş Tarihi): 02.10.2019 Accepted (Kabul Tarihi): 16.02.2020 


\section{INTRODUCTION}

Pressure ulcer is the injury that is usually caused by pressure, shear or a pressure in combination with shear on the skin and/or subcutaneous tissues on bone prominence areas. ${ }^{[1]}$ Pressure ulcer is a major healthcare problem which is preventable and requiring a longterm hospitalization with a high level of disability and dependency that may be associated with infection and sepsis. ${ }^{[2]}$ While the incidence of pressure ulsers is $10-23 \%$ inside the hospital, this ratio was reported to be between $8.1 \%$ and $41 \%$ in intensive care units. ${ }^{[3-7]}$ In Turkey, the incidence of pressure ulcers was reported to be $17 \%$ in intensive care units and $15.5 \%$ among the patients who underwent a mechanical ventilation treatment at least for 24 hours. $^{[8,9]}$

More than a hundred factors causing pressure ulcers were identified in the literature. ${ }^{[1-9]}$ Intensive care patients constitute a patient group having multiple risks especially for pressure ulcers. Pressure ulcer makes patient to feel pain, delays the treatment of primary disease and decreases the quality of life following discharge. This condition is an important healthcare problem that negatively affects life quality and increases treatments costs; and it is a significant problem especially in the countries with limited resources allocated from the global budget for healthcare. ${ }^{[2,10]}$ Pressure ulcers, especially which are due to inactivity, are commonly seen among the patient groups which are old and have weakened sensory functions. Patients on mechanical ventilatory support are suspected to develop pressure ulcers due to the limitation of movement, sensory loss due to sedation and analgesia, maceration due to incontinence, sweating, hemodynamic and oxygenation disorders. ${ }^{[7]}$ Considering that mechanical ventilator is a complicating factor for moving the patient inside the bed, it is suggested to have a significant association with pressure ulcer risk.

Pressure ulcers are among the indicators of nursing care quality. It has been emphasized that $90 \%$ of pressure ulcers can be prevented by accurate risk assessment and appropriate nursing care. ${ }^{[10]}$ Although the occurrence or recurrence of pressure ulcers may be prevented simply by removing pressure, modern medical world could not have reduced the incidence of this common clinical problem significantly. It was reported that patients, who developed pressure ulcers, were hospitalized for a long time, and caused a major economic and workpower loss. ${ }^{[11,12]}$ Pressure ulcers that were developed in older patients hospitalized due to trauma, were reported to be worsened in one third of them. ${ }^{[13]}$ Most of the pressure ulcers develop within 24-48 hours following immobility. Therefore, it is required to apply patient-specific treatment plans within the first 24 hours together with protective measures for risky patients. ${ }^{[11,12]}$

Since mobilization and in-bed positions are restricted in patients having mechanical ventilation treatment, there is a risk for developing pressure ulcers. On the other hand, oxygenation support with mechanical ventilation treatment provides oxygenation of the tissues. ${ }^{[2,7]}$ With this respect, research data regarding the incidence and reasons of the development of pressure ulcers among the patients on mechanical ventilation are limited.

The aim of this study was to detect the incidence of pressure ulcers among the patients who were initiated mechanical ventilation treatment and to identify risk factors for the development of pressure ulcers.

\section{MATERIAL AND METHOD}

Design: This study was cross-sectional and prospective.

Setting: The study was conducted in 5 intensive care units of a state hospital in Western Black Sea Region which provide service for second and third level internal medicine, surgical and mixed patient groups. Bed capacities of these intensive care units were between 9 and 15 . One nurse was providing care for every three patients.

Sample: The sample of the study included 260 patients who were initiated mechanical ventilation treatment between January 29, 2017 and January 29, 2018. Sample inclusion criteria were determined as being older than 18 years old, undergoing mechanical ventilation treatment for more than 48 hours, lack of pressure ulcers at first assessment and having an albumin level above 2,5 during the treatment.

Data Collection Instruments: Patient information form which was generated in accordance with the literature, Braden Risk Assessment Scale and guidelines which were published by European Pressure Ulcer Advisory Panel and National Pressure Ulcer Advisory Panel were used. The data were collected by only one researcher.

Patient information form: Data regarding sociodemographics and medical conditions of the patients were queried with this form. Patients' states of consciousness and motor responses were assessed based on Glasgow Coma Scale.

Braden Risk Assessment Scale: It was used to determine pressure ulcer risk of the patients. This 
scale was developed by Braden and Bergstrom; and its validity and reliability were found to be high in Turkey by Pinar and Oguz. ${ }^{[14]}$ The scale is gathered under 6 main headings including perception of the stimulus, humidity, activity, motility, nutrition, friction and irritation. A total score ranging between 6-23 is obtained by the sum of its subscale scores. Based on total score, 12 points and below are assessed as high risk, 13-14 as risky and 15-16 as low risk; and 15-18 points are considered as low risk among the individuals aged above 75 years old. ${ }^{[14]}$

The Guideline published by European Pressure Ulcer Advisory Panel and National Pressure Ulcer Advisory

Panel: The staging of pressure ulcers was defined by this guideline. According to this, pressure ulcers are classified in 4 stages. Classification is as follows;

Stage I; Non-blanchable erythema of intact skin generally with a localized area over bone prominence.

Stage II; Partial-thickness loss of skin with exposed dermis that appears as a superficial open ulcer and having a wound bed in pink or red color without a yellow necrotic tissue.

Stage III; There is a full-thickness skin loss. Adipose tissue can be visible in the wound bed; but, bone, tendon or muscles are not exposed.

Stage IV; There is a full-thickness loss of skin and tissue in which bones, tendon or muscles are affected. ${ }^{[1]}$

Data Collection Process: At first evaluation of the patients who were decided to initiate mechanical ventilation treatment and met the inclusion criteria, their descriptive data and pressure ulcer risk were identified. In this study, patients were provided to get routine nursing care given in the clinic. Routine nursing interventions to prevent pressure ulcers in these intensive care units were changing position every 2 hours, adjusting dietary plan by cooperating with nutrition specialists, cleaning and care for incontinence, daily wiping bath, use of air bearing pad for the patients who were at high risk for developing pressure ulcer, daily control of the pressure of air bearing pad, providing the organization of beds and sheets and daily assessment of the skin. Pressure ulcers that developed at three timepoints including 10th hour, 1 st week and 2 nd week after the initiation of mechanical ventilation treatment and the areas where they developed were recorded. Evaluation of all patients was carried out by the same researcher. A treatment was started to heal these pressure ulcers.

Data Analysis: Data obtained in the study were analyzed by using SPSS for Windows 18 program. Normality of the distribution was evaluated with
Kolmogrov-Smirnov test. Numbers, percentages, mean and standart deviation analyses were used to evaluate variables that were included in demographic and clinical characteristics of patients. Student's t test was used to compare independent variables between two groups; and Anova was used to compare three and more groups. The correlation between independent variables and Braden Risk Assessment Scale was tested by Pearson correlation analysis. A $p$ value of $<0.05$ was considered as statistically significant.

Ethical Considerations: Ethics approval was provided by Karabuk University Non-interventional Clinical Research Ethics Committee (date no: 01.25.2017, call no:1/2) and institutional authorization was given by the head physician of the hospital. The authors of the scale having validity and reliability in Turkish were asked for a permission to use through email. The guardians of the patients were informed about the aim of the study and they were told that all data would be used for scientific purposes; and their consents were taken.

\section{RESULTS}

\section{Demographic and Clinical Characteristics}

Mean age of the patients included in the study was $54 \pm 10$ years old; $47.3 \%$ were women and $52.7 \%$ were men. $28 \%$ of the patients were hospitalized in the mixed intensive care unit which accepted surgical as well as internal medicine patients. State of consciousness was confused among $52.3 \%$ of the patients, $63.1 \%$ showed a motor response as localizes to pain and $55.4 \%$ of them had a body mass index within normal range. When an assessment was done for the other health variables of the patients, it was found that blood glucose was $102.5 \pm 15.35 \mathrm{mg} / \mathrm{dl}$; albumin was $2.98 \pm 0.11$; hemoglobin was 11.01 \pm 1.5 ; hematocrit was $42.2 \pm 2.27$; leukocytes were $6.02 \pm 1.23$; oxygen saturation was $96.45 \pm 2.48$ $\left(\mathrm{SaO}_{2}\right)$; partial oxygen pressure $\left(\mathrm{PaO}_{2}\right)$ was $60.75 \pm 2.09$; partial carbondioxide pressure $\left(\mathrm{PaCO}_{2}\right)$ was $42.79 \pm 2.78$; blood $\mathrm{pH}$ was $7.44 \pm 0.01$; and Braden Risk Assessment Scale score was $11.0 \pm 2.64$. When existing health problems of the patients were examined, it was detected to be cerebrovascular event in $46.5 \%$, respiratory system diseases in $25.4 \%$, spinal cord injury in $21.7 \%$ and cancer in $4.2 \%$. Infection symptoms were seen among $39.6 \%$ and allergy was present among $7.7 \%$ of the patients. Vasopressor and sedative medications were found during the treatment of $35.8 \%$ of the patients (Table 1). 


\begin{tabular}{|c|c|c|}
\hline Variables & $\mathbf{n}$ & $\%$ \\
\hline \multicolumn{3}{|l|}{ Gender } \\
\hline Female & 123 & 47.3 \\
\hline Male & 137 & 52.7 \\
\hline \multicolumn{3}{|l|}{ Service } \\
\hline Internal intensive care & 45 & 17.3 \\
\hline Neurology intensive care & 67 & 25.7 \\
\hline Anesthesia intensive care & 45 & 17.3 \\
\hline Coroner intensive care & 30 & 11.5 \\
\hline Mixed intensive care & 73 & 28.0 \\
\hline \multicolumn{3}{|l|}{ Mental Condition } \\
\hline Oriented & 85 & 32.7 \\
\hline Confused & 136 & 52.3 \\
\hline Stupor & 9 & 3.5 \\
\hline Precoma & 30 & 11.5 \\
\hline Coma & 0 & 0 \\
\hline \multicolumn{3}{|l|}{ Motor Response } \\
\hline Obeys commands & 30 & 111.5 \\
\hline Localizes to pain & 164 & 63.1 \\
\hline Withdrawal from pain & 22 & 8.5 \\
\hline Decorticate posturing & 44 & 16.9 \\
\hline Decerebrate posturing & 0 & 0 \\
\hline No motor response & 0 & 0 \\
\hline \multicolumn{3}{|l|}{ Body Mass Index } \\
\hline Underweight & 44 & 16.9 \\
\hline Normal & 144 & 55.4 \\
\hline Overweight & 61 & 23.5 \\
\hline Obesity & 11 & 4.2 \\
\hline \multicolumn{3}{|l|}{ Current Health Problems* } \\
\hline C er ebr o $v$ ascular event & 121 & 46.5 \\
\hline Respiratory System Diseases & 66 & 25.4 \\
\hline Spinal Cord Injury & 55 & 21.7 \\
\hline Cancer & 11 & 4.2 \\
\hline Other (Diyabetes Mellitus, immunosupression) & 7 & 2.7 \\
\hline \multicolumn{3}{|l|}{ Systemic Infection Status } \\
\hline Yes & 103 & 39.6 \\
\hline No & 157 & 60.4 \\
\hline \multicolumn{3}{|l|}{ Alergy Condition } \\
\hline Yes & 20 & 7.7 \\
\hline No & 240 & 92.3 \\
\hline \multicolumn{3}{|l|}{ Medication } \\
\hline Vazopressor & 93 & 35.8 \\
\hline Sedatives & 93 & 35.8 \\
\hline Other (Steroids, cytotoxics, antiinflammatories) & 3 & 1.6 \\
\hline General Health Status & $\mathrm{x}$ & SD \\
\hline Age & 54.38 & 10.0 \\
\hline Blood Glucose & 102.5 & 15.35 \\
\hline Albumin & 2.98 & 0.11 \\
\hline Hemoglobin & 11.01 & 1.5 \\
\hline Hemotocrit & 42.2 & 2.27 \\
\hline Leukocyte & 6.02 & 1.23 \\
\hline $\mathrm{SaO}_{2}$ & 96.45 & 2.48 \\
\hline $\mathrm{PaO}_{2}$ & 60.75 & 2.09 \\
\hline $\mathrm{PaCO}_{2}$ & 42.79 & 2.78 \\
\hline $\mathrm{pH}$ & 7.44 & 0.01 \\
\hline Braden Risk Assessment Scale Score & 11.00 & 2.64 \\
\hline
\end{tabular}

\begin{tabular}{|c|c|c|c|c|}
\hline Variables & Mean & Sd & $t / F$ & $\mathbf{p}$ \\
\hline \multicolumn{5}{|l|}{ Gender } \\
\hline Female & 10.69 & 2.44 & \multirow{2}{*}{5.95} & \multirow{2}{*}{0.01} \\
\hline Male & 11.27 & 2.78 & & \\
\hline \multicolumn{5}{|l|}{ Service } \\
\hline Internal intensive care & 10.91 & 2.73 & \multirow{5}{*}{0.85} & \multirow{5}{*}{0.49} \\
\hline Neurology intensive care & 11.01 & 2.53 & & \\
\hline Anesthesia intensive care & 10.64 & 2.06 & & \\
\hline Coroner intensive care & 11.76 & 2.92 & & \\
\hline Mixed intensive care & 10.94 & 2.88 & & \\
\hline \multicolumn{5}{|l|}{ Mental Condition } \\
\hline Oriented & 13.72 & 2.48 & \multirow{4}{*}{97.56} & \multirow{4}{*}{0.00} \\
\hline Confused & 9.50 & 1.09 & & \\
\hline Stupor & 9.44 & 1.13 & & \\
\hline Precoma & 10.50 & 2.31 & & \\
\hline \multicolumn{5}{|l|}{ Motor Response } \\
\hline Obeys commands & 12.70 & 2.26 & \multirow{4}{*}{9.54} & \multirow{4}{*}{0.00} \\
\hline Localizes to pain & 10.40 & 2.30 & & \\
\hline Withdrawal from pain & 11.27 & 2.96 & & \\
\hline Decorticate posturing & 11.90 & 3.02 & & \\
\hline \multicolumn{5}{|l|}{ Body Mass Index } \\
\hline Underweight & 10.65 & 2.52 & \multirow{4}{*}{0.84} & \multirow{4}{*}{0.47} \\
\hline Normal & 11.22 & 2.73 & & \\
\hline Overweight & 10.78 & 2.58 & & \\
\hline Obesity & 10.54 & 2.11 & & \\
\hline \multicolumn{5}{|l|}{ Systemic İnfection Status } \\
\hline Yes & 10.76 & 2.73 & \multirow{2}{*}{0.29} & \multirow{2}{*}{0.58} \\
\hline No & 11.15 & 2.57 & & \\
\hline
\end{tabular}

\section{Pressure Ulcer Development Risk and Affecting Factors}

In this study, pressure ulcer development risk was compared with some variables. Accordingly, pressure ulcer development risk was found to be significantly higher among women $(t=5.95, p=0.01)$, patients with a state of consciousness as stupor $(F=97.56, p=0.00)$ and patients who showed a motor response as localizes to pain $(F=9.54, p=0.00)$. In this study, pressure ulcer development risk was compared with some variables. Accordingly, pressure ulcer development risk was found to be significantly higher among women ( $t=5.95, p=0.01$ ), patients with a state of consciousness as stupor ( $F=97.56$, $\mathrm{p}=0.00$ ) and patients who showed a motor response as localizes to pain ( $F=9.54, p=0.00$ ). The correlation between some characteristics of the patients and total score from Braden Risk Assessment Scale was also assessed. A negative and statistically significant correlation was found between $\mathrm{PaCO}_{2}$ level of the patients and their total score from Braden Risk Assessment Scale ( $r=-0.04$, $\mathrm{p}=0.52$ ). The correlations between age, body mass index, blood glucose, hematocrit, albumin, leukocytes, blood $\mathrm{pH}$, saturation percentage, partial oxygen pressure and total score from Braden Risk Assessment Scale score were not found to be statistically significant (Table 3). 
Table 3. Relationship between some variables and braden risk assessment

\begin{tabular}{lcccc} 
Variables & $\mathbf{X}$ & $\mathbf{S d}$ & $\mathbf{r}$ & $\mathbf{p}$ \\
\hline Age & 54.38 & 10,0 & 0.07 & 0.24 \\
$\mathrm{BMI}$ & 22.94 & 3.59 & -0.05 & 0.41 \\
Blood Glucose & 102.5 & 15.35 & 0.05 & 0.38 \\
Albumin & 2.98 & 0.11 & -0.06 & 0.27 \\
Hemoglobin & 11.01 & 1.5 & 0.00 & 0.91 \\
Hemotocrit & 42.2 & 2.27 & 0.05 & 0.38 \\
Leukocyte & 6.02 & 1.23 & 0.02 & 0.68 \\
$\mathrm{SaO}_{2}$ & 96.45 & 2.48 & -0.04 & 0.43 \\
$\mathrm{PaO}_{2}$ & 60.75 & 2.09 & -0.04 & 0.48 \\
$\mathrm{PaCO}_{2}$ & 42.79 & 2.78 & -0.23 & 0.00 \\
$\mathrm{pH}$ & 7.44 & 0.01 & -0.04 & 0.52 \\
\hline
\end{tabular}

\section{State of Developing Pressure Ulcers}

During evaluation at 10th hour following the initiation of mechanical ventilation treatment, it was found that there was no impairment in the skin integrity among $89.2 \%$ of the patients $(n=232)$, and Stage I pressure ulcer was developed on sacrum and right heel in 3.5\% $(n=9)$, on coccyx in $2.3 \%(n=6)$ and on left heel in $1.5 \%(n=4)$ (Graphic 1). The incidence of Stage I pressure ulcer was found to be $10.8 \%$ at 10 hours.

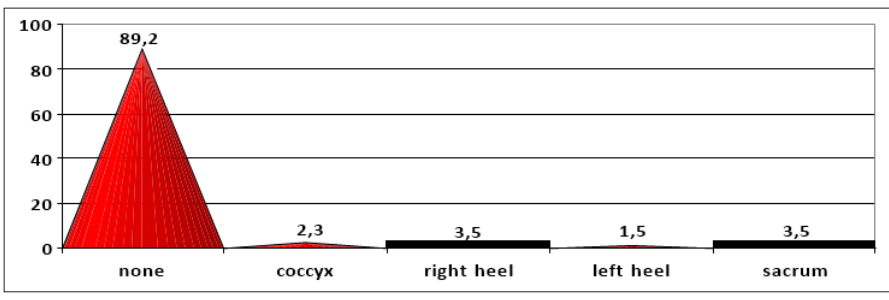

Graphic 1. Developed a pressure ulcers regions at 10th hour

During evaluation at first week after the initiation of mechanical ventilation treatment, it was found that there was no impairment in the skin integrity among $41.5 \%$ of the patients $(n=108)$, and Stage I pressure ulcer was developed on sacrum in $23.1 \%(n=60)$, on coccyx in $19.2 \%(n=50)$ and on the nape, iliac bone, ear, ankle and heel regions at varying rates between $0.4 \%(n=1)$ and $6.9 \%(n=18)$ (Graphic 2). The incidence of Stage I pressure ulcer at first week was found to be $58.5 \%$.

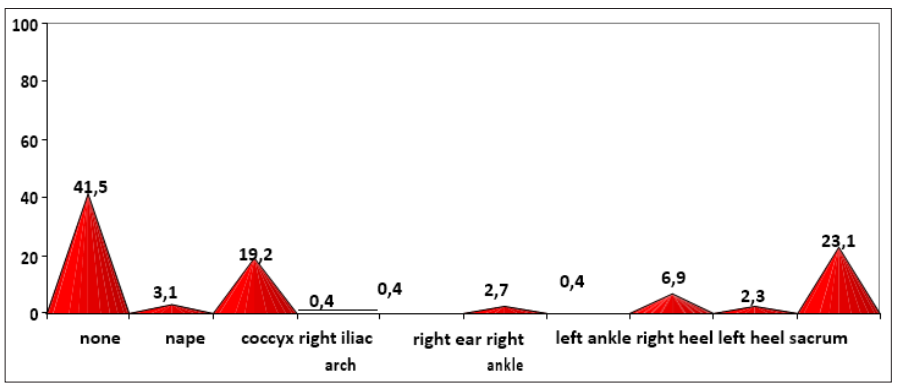

Graphic 2. Developed a pressure ulcers regions in the first week
During evaluation at second week after the initiation of mechanical ventilation treatment, it was found that there was no impairment in the skin integrity among $28.1 \%$ of the patients $(n=73)$; but, Stage I pressure ulcer was developed on sacrum in $30 \%(n=78)$, on coccyx in $22.7 \%(n=59)$ and on the nape, iliac bone, ear, ankle and heel regions at varying rates between $0.4 \%(n=1)$ and $7.7 \%(n=20)$ (Graphic 3$)$. The incidence of Stage I pressure ulcer at second week was found to be $71.15 \%$. A transition to Stage II pressure ulcer was observed only in two patients who had Stage I pressure ulcer on the sacrum. The incidence of Stage II pressure ulcer was identified to be $0.76 \%$ at second week.

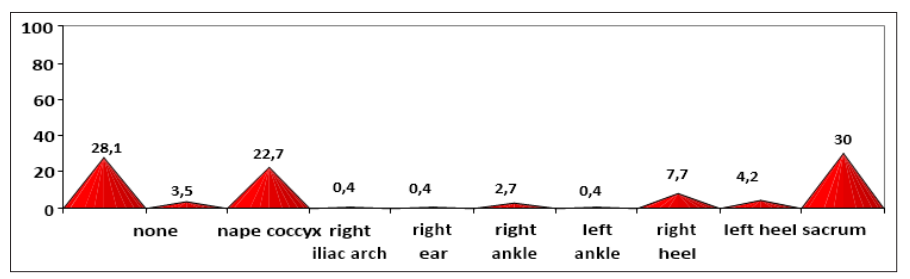

Graphic 3. Developed a pressure ulcers regions in the second week

\section{State of Developing Pressure Ulcers}

During evaluation at 10th hour following the initiation of mechanical ventilation treatment, it was found that there was no impairment in the skin integrity among $89.2 \%$ of the patients ( $n=232)$, and Stage I pressure ulcer was developed on sacrum and right heel in $3.5 \%(n=9)$, on coccyx in $2.3 \%(n=6)$ and on left heel in $1.5 \%(n=4)$ (Graphic 1). The incidence of Stage I pressure ulcer was found to be $10.8 \%$ at 10 hours.

During evaluation at first week after the initiation of mechanical ventilation treatment, it was found that there was no impairment in the skin integrity among $41.5 \%$ of the patients $(n=108)$, and Stage I pressure ulcer was developed on sacrum in $23.1 \%(n=60)$, on coccyx in $19.2 \%(n=50)$ and on the nape, iliac bone, ear, ankle and heel regions at varying rates between $0.4 \%(n=1)$ and $6.9 \%(n=18)$ (Graphic 2). The incidence of Stage I pressure ulcer at first week was found to be $58.5 \%$.

During evaluation at second week after the initiation of mechanical ventilation treatment, it was found that there was no impairment in the skin integrity among $28.1 \%$ of the patients ( $n=73)$; but, Stage I pressure ulcer was developed on sacrum in $30 \%(n=78)$, on coccyx in $22.7 \%(n=59)$ and on the nape, iliac bone, ear, ankle and heel regions at varying rates between $0.4 \%(n=1)$ and $7.7 \%(n=20)$ (Graphic 3). The incidence of Stage I pressure ulcer at second week was found to be $71.15 \%$. 
A transition to Stage II pressure ulcer was observed only in two patients who had Stage I pressure ulcer on the sacrum. The incidence of Stage II pressure ulcer was identified to be $0.76 \%$ at second week.

\section{DISCUSSION}

In this study, the incidence of pressure ulcer development and the areas where they developed were evaluated at three different timepoints among the patients who were hospitalized in intensive care units and began to undergo mechanical ventilation treatment. Mechanical ventilation treatment has been reported to be a factor causing pressure ulcers due to its impairing effect on blood circulation at epidermal and subcutaneous tissue and on the balance between ventilation-perfusion by affecting pumping function of the heart. ${ }^{[9,11]}$ In a study which was conducted in six centers, it was indicated that patients who were on mechanical ventilation treatment were at a higher risk compared to the others receiving inpatient treatment. ${ }^{[3]}$ In a study which was carried out in surgical intensive care units, development of pressure ulcers was significantly enhanced by the increase in the days of ventilation, dialysis and gaita incontinence; and besides, the number of days for using norepinephrine and lactic acid level in arterial blood were determined to create a high risk for pressure ulcers. ${ }^{[11]}$ At the end of this current study, majority of the patients, who were accepted to intensive care, were found to be hospitalized due to the diagnoses of cerebrovascular event, respiratory system diseases and spinal cord injury. In addition to the disturbance in respirationcirculation and sensory-motor functions by these diseases, pressure ulcer risk was found to be increased by the initiation of mechanical ventilation treatment. Advanced age has been known to be a factor in the development of pressure ulcers due to its outcomes such as decrease in skin elasticity, chronic diseases and sensory defects. However, various results were found about the relationship between age and development of pressure ulcers in the previous studies. ${ }^{[4,13]}$ The mean age of the patients included in this study showed that they were not included in advanced age group; but, development of pressure ulcers was enhanced with the extension of the duration of mechanical ventilation treatment.

In the literature, the studies investigating the possibility that age may be a factor for the development of pressure ulcers, showed difference results. ${ }^{[15,16]}$ Pressure ulcer risk was found to be significantly higher among women in this study. This situation may be explained by some basic physiological differences between women and men which may be associated with pressure ulcer development. ${ }^{[15]}$ Due to the facts that women have a larger pelvis, two times more adipose tissue, less percentage of muscle mass, and weaker muscle tone and strength, the risk for the development of pressure ulcers may be increased. Some risk factors have been described for the development of pressure ulcers including extrinsic factors such as pressure, friction, shear and moist, and intrinsic factors such as limited physical activity and mobilization, use of anesthetic, sedative and neuromuscular blocking agents, reduction in sensual perception and circulatory and ventilatory disorders. $^{[1,2]}$ Mechanical ventilation treatment may make adverse effects of extrinsic as well as intrinsic factors more negative. It has been reported that stage I pressure ulcers occur within an average of 1-10 days in the intensive care units. ${ }^{[4,8]}$ In the previous studies, it was shown that pressure ulcers developed significantly at second week of mechanical ventilation treatment and mechanical ventilation treatment lasting longer than 20 days might be associated with pressure ulcers. ${ }^{[3,9]}$ At the end of this current study, the incidence of stage I pressure ulcer was found to be $10.8 \%$ at 10 hours after the initiation of mechanical ventilation treatment and the incidences were found to be $58.5 \%$ at first week and $71.15 \%$ at second week as parallel to the data in the literature. This situation confirmed that pressure ulcer development rates increased with the extension of the duration of mechanical ventilation treatment.

$\mathrm{SaO}_{2}, \mathrm{PaO}_{2}$ and $\mathrm{PaCO}_{2}$ values of the patients are among the parameters showing the efficiency of mechanical ventilation treatment. However, it may be sometimes difficult to maintain these values within the desired range due to several reasons such as respiratory and circulatory diseases, acid-base imbalances and care interventions. In the study by Karayurt et al., pressure ulcers were found to be developed significantly with the decreases in $\mathrm{PaO}_{2}$ and $\mathrm{SaO}_{2}$ levels and increase in $\mathrm{PaCO}_{2}$ levels. ${ }^{[9]}$ In another study evaluating trauma patients, a significant relationship was revealed between decreasing hemoglobin level and $\mathrm{O}_{2}$ saturation and the development of pressure ulcer. ${ }^{[13]}$ The negative correlation between pressure ulcer development risk and $\mathrm{PaCO}_{2}$ in this study reminded the necessity for following up this condition together with other variables.

In the national and international studies, the areas where pressure ulcers developed among the patients treated in intensive care were reported to be mostly sacrum, coccyx, trochanter and heels. ${ }^{[7,17,18]}$ Since patients undergoing 
mechanical ventilation treatment often stay in supine position, pressure is increased on these areas. In this study, stage I pressure ulcers were found to develop on sacrum and coccyx at a ratio of $2-3 \%$ at 10 hours after the initiation of mechanical ventilation treatment, and these ratios increased up to $20 \mathrm{~s} \%$ at first week and $30 \%$ at second week. Development of pressure ulcer represents the inadequacy in nursing care quality and development of stage III or IV pressure ulcer is considered as a "never intolerable" event. ${ }^{[10]}$ In a study that was performed in India, a high incidence was reported for stage 3 pressure ulcers on sacrum and heel[19]; and in a study performed in Portugal, a high prevalence of stage 1 pressure ulcer was reported on sacrum and coccyx. ${ }^{[20]}$

In this study, it was observed that stage 1 pressure ulcers that were seen at second week of mechanical ventilation treatment showed a bad course towards stage 2. This situation reminded that incidences of stage 1 and 2 pressure ulcers might be increased among the intensive care patients requiring long term treatment.

The results of this study showed that the incidence of pressure ulcers increased with the extension of the duration of treatment among the patients who underwent mechanical ventilation treatment; and therefore, it is absolutely necessary to practice additional interventions for the prevention of pressure ulcers in this patient group. Knowing the risk of pressure ulcer development and the areas where they mostly develop will be guiding for the measures to be taken. The frequent use of supine position as a result of mechanical ventilation treatment will increase the risk on coccyx and sacrum regions. ${ }^{[7]}$ According to the results of a systematic review including the studies performed in Turkey, it was revealed that nurses performed a limited number of interventions to prevent pressure ulcers, clinical decisions were insufficient and the follow ups were not conducted. ${ }^{[10]}$ Yet, nurses can use their independent roles more efficiently and they can contribute to the reduction of hospitalization time, increase in the life quality of the patient and avoidance of economic losses.

\section{CONCLUSIONS}

It was observed that the development of pressure ulcers enhanced with the extension of the duration of treatment among the patients who were initiated mechanical ventilation treatment. Besides, coccyx and sacrum were found to be the regions where pressure ulcers mostly develop. An attention must paid on the care of these regions in order to prevent the formation of pressure ulcers. Based on this, it is highly important for the intensive care nurses to be aware of the high incidence of pressure ulcers among the patients who undergo mechanical ventilation treatment and to take necessary precautions. Since the risk of developing pressure ulcer is higher especially among women and patients having a worsening state of consciousness, additional precautions must be taken for this patient gorup. Considering that the incidence of Stage 1 pressure ulcers will highly increase at second week of mechanical ventilation and there will be transitions to Stage 2, interventions for speeding up recovery process of the patients should be increased. Inservice trainings should be given regularly and evaluations should be performed to prevent pressure ulcers. It can be suggested to perform long term and prospective incidence studies on the intensive care patients who undergo mechanical ventilation treatment.

\section{ETHICAL DECLARATIONS}

Ethics Comittee Approval: The study was carried out with the permission of Karabuk University Noninterventional Clinical Research Ethics Committee (date no: 01.25.2017, call no:1/2) and institutional authorization was given by the head physician of the hospital.

Informed Consent: Written informed consent was obtained from all participants who participated in this study.

Status of Peer-review: Externally peer-reviewed.

Conflict of Interest Statement: The authors have no conflicts of interest to declare.

Financial Disclosure: The authors declared that this study has received no financial support.

Author Contributions: All of the authors declare that they have all participated in the design, execution, and analysis of the paper, and that they have approved the final version.

\section{REFERENCES}

1. National Pressure Ulcer Advisory Panel, Europan Pressure Ulcer Advisory Panel and Pan Pacific Pressure Injury Alliance. (2014). Prevention and treatment of pressure ulcers: quick reference guide. (Publication No: 978-0-9579343-6-8) Cambridge Media: Perth, Australia. Emily Haesler (Ed.)..[updated 2014; cited 18 October 2019] Available from: https://www.npuap. org/wp-content/uploads/2014/08/Updated-10-16-14-QuickReferenceGuide-DIGITAL-NPUAP-EPUAP-PPPIA-160ct2014.pdf

2. National Institute for Health and Care Excellence. (2014). Pressure ulcers: Prevention and management, Clinical guideline. (Publication No: CG179)...[updated 2014, cited 18 October, 2019] Available from: nice.org.uk/guidance/cg179 
3. Apostolopoulou $E_{1}$ Tselebis A, Terzis $K$, Kamarinou $E$, Lambropoulos I, Kalliakmanis A. Pressure ulcer incidence and risk factors in ventilated intensive care patients. Health Science Journal 2014;8 (3):333-342

4. Borghardt AT, Prado TN, Bicudo SDS, Castro DS, Bringuente MEO. Pressure ulcers in critically ill patients: incidence and associated factors. Rev Bras Enferm 2016;69(3):431-8.

5. Cooper KL. Evidence-based prevention of pressure ulcers in the Intensive care unit. Crit Care Nurse 2013;33(6):57-67.

6. González-Méndez MI, Lima-Serrano M, Martín-Castaño C, AlonsoAraujo I,Lima-Rodríguez JS. Incidence and risk factors associated with the development of pressure ulcers in an intensive care unit. J Clin Nurs 2018;27(5-6):1028-1037

7. Nijs N, Toppets A, Defloor T, Bernaerts K, Milisen K, Van Den Berghe G.Incidence and risk factors for pressure ulcers in the intensive care unit. J Clin Nurs 2009; 18(9):1258-66

8. Özyürek P, Yavuz Van Giersbergen M, Yildiz Ö. Investigation of the risk factors of pressure ulcers in intensive care unit patient according to the Braden Scale, East J Med 2016; 21(1):1-9.

9. Karayurt Ö, Akyol Ö, Kılıçaslan N, Akgün N, Sargın Ü, Kondakçı M, et al. The incidence of pressure ulcer in patients on mechanical ventilation and effects of selected risk factors on pressure ulcer development. Turk J Med Sci 2016; 46(5):1314-1322.

10.Çınar F, Kula Şahin Ş, Eti Aslan F. Evaluation of studies in Turkey on the prevention of pressure sores in the intensive care unit: a systematic review. Balıkesir Health Sciences Journal 2018; 7(1): 42-50.

11.Wang XR, Han BR. Logistic regression analysis and nursing interventions for high-risk factors for pressure sores in patients in a surgical intensive care unit. Chin Nurs Res 2015; 2(2-3): 5154.

12. Mitchell A. Adult pressure area care: preventing pressure ulcers. Br J Nurs 2018; 4;27(18):1050-1052.

13.Alderden J, Zhao YL, Zhang Y, Thomas D, Butcher R, Zhang Y, et al. Outcomes associated with stage 1 pressure injuries: a retrospective cohort study. Am J Crit Care 2018 Nov;27(6):471476.

14.Pınar R, Oğuz S. Norton ve Braden Bası Yarası değerlendirme ölçeklerinin yatağa bağımlı aynı hasta grubunda güvenirlik ve geçerliğinin sınanması: Uluslar arası katılımlı VI. Ulusal Hemşirelik Kongresi, Kongre Kitabı, Ankara; 1998. p.172-5.

15.Latifa K, Sondess S, Hajer G, Manel BH, Souhir K, Nadia B, et al. Evaluation of physiological risk factors, oxidant-antioxidant imbalance, proteolytic and genetic variations of matrix metalloproteinase-9 in patients with pressure ulcer. Sci Rep 2016; 11(6):29371.

16. He M, Tang A, Ge X, Zheng J. Pressure ulcers in the intensive care unit: an analysis of skin barrier risk factors. Adv Skin Wound Care. 2016;29(11):493-498.

17.KıranerE, Terzi B, Uzun Ekinci A, Tunalı B. Yoğun bakım ünitemizdeki basınç yarası insidansı ve risk faktörlerinin belirlenmesi. Yoğun Bakım Hemşireliği Dergisi. 2016; 20(2): 7883.

18.Loudet $\mathrm{Cl}$, Marchena MC, Maradeo MR, Fernández SL, Romero $\mathrm{MV}$, Valenzuela GE, et al. Reducing pressure ulcers in patients with prolonged acute mechanical ventilation: A quasi-experimental study. Rev Bras Ter Intensiva. 2017; 29(1):39-46.

19.Mehta C, George JV, Mehta Y, Wangmo N. Pressure ulcer and patient characteristics--A point prevalence study in a tertiary hospital of India based on the European Pressure Ulcer Advisory Panel minimum data set. J Tissue Viability. 2015;24(3):123-30.

20.Garcez Sardo PM, Simões CS, Alvarelhão JJ, de Oliveira e Costa CT, Simões CJ, Fiqueira JM, et al. Analyses of pressure ulcer point prevalence at the first skin assessment in a Portuguese Hospital. J Tissue Viability. 2016;25(2):75-82. 